\title{
Public trust doctrine, research and responsible wildlife management in South Africa
}

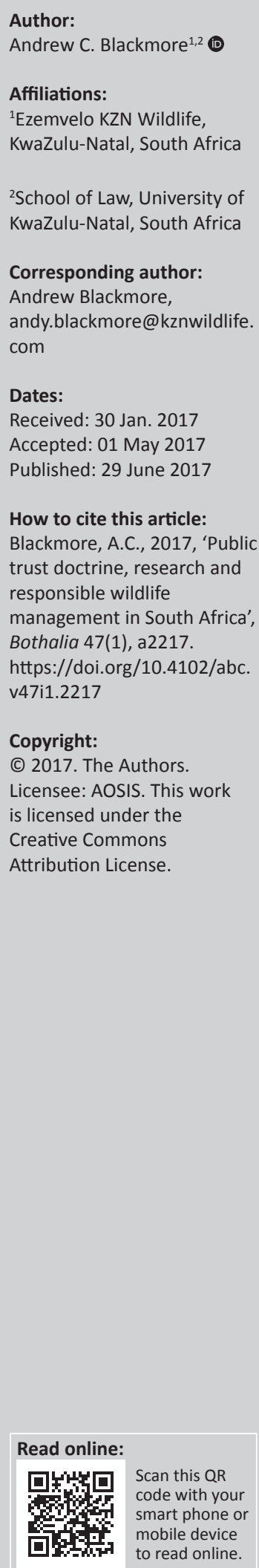

\begin{abstract}
A significant proportion of South African biodiversity occurs in extensive private wildlife areas. As such, the continuance of these private reserves is paramount to conservation of the country's biodiversity. The areas are, however, vulnerable to being divided into smaller camps as landowners enter into the new and rapidly growing industry of selective breeding and intensive management of antelope and predators. Concerns are being raised as to the longterm consequences of the products and impacts of this industry on, inter alia, integrity and conservation of the country's wildlife, and the landscapes these facilities are located in, as well as the country's reputation as a free ranging and fair chase hunting destination. Using the public trust doctrine as a foundation, this article characterises the relationship between the country's environmental law and the roles played by government as the regulator, the wildlife industry, research and the public in achieving responsible wildlife management and the long-term conservation of this resource. These relationships are seen to be finely balanced between the provision of robust science, and evidence-based and cautious or risk-averse decision-making. It is concluded that the public trust doctrine is a powerful tool to limit the impacts of unsustainable and parochial use of wildlife on the conservation of biodiversity. It is also concluded that an improved understanding of the doctrine by researchers, public and the wildlife industry would lead to a greater relevance of research, and in turn sound evidencebased decision-making and ultimately sustainable use of wildlife.
\end{abstract}

\section{Introduction}

Globally, the conservation of wildlife is under great pressure with an increasing number of species being listed as vulnerable, threatened or endangered. The rapid decline of wildlife in the late 1800s through unsustainable hunting (Hoffmann \& Jungius 1972) precipitated the drafting of the Convention of the Preservation of Wild Animals, Birds and Fish in Africa (1900 London Convention). Although this convention never came into force, it is regarded as the first multilateral realisation of the threat that the 'indiscriminate slaughter' of game was having on wildlife populations (Preamble to the Convention). This convention was replaced by the Convention Relative to the Preservation of Fauna and Flora in their Natural State (1933 London Convention), which came into force in 1936, and which was in turn replaced by the 1968 African Convention on the Conservation of Nature and Natural Resources (Algiers Convention), which is currently still in force. Throughout these revisions, an increasing emphasis was placed on the economic values of wildlife (for example sport hunting and tourism) as well as inter alia, scientific and research, educational, cultural and aesthetic values (Hoffmann \& Jungius 1972). The Algiers Convention was substantially reviewed and updated by the (revised) African Convention on Conservation of Nature and Natural Resources, which was signed into being in Maputo in 2003 (the Maputo Convention), but this is yet to come into force. The Maputo Convention consolidated the trend towards sustainable use of wildlife as well as a landscape approach to conservation of biodiversity. In addition, the 1992 South African Development Community (SADC) Treaty and its derivative, the 1999 Protocol on Wildlife Conservation and Law Enforcement, recognised the economic value and hence the need for a collective effort by the African states to safeguard their wildlife through sustainable use and conservation. Towards achieving this objective, the Protocol sets in place a number of obligations on the SADC region to give effect to legislation and enforcement, and decisions authorising or prohibiting use of wildlife.

Since the realisation of the value of game in the 1970s, the number of game farms or extensive private wildlife areas has grown to approximately $16.8 \%$ of South Africa's landmass (Cousins, Sadler \& Evans 2010). It is argued that these extensive wildlife areas make a significant contribution to the conservation of biodiversity at a landscape and country level (Luxmoore 1985; Trimble \& Van Aarde 2014). Given the considerable rate of transformation of natural land in South Africa 
(Dobson et al. 2006; Jewitt et al. 2015) it stands to reason that not only the retention of these areas as extensive wildlife systems, but also the responsible management of the wildlife therein is an important, if not crucial, consideration in the conservation of this component of biodiversity.

Responsible wildlife management may be characterised from a variety of perspectives in the short to long term. This characterisation may be based upon the gradient from which 'irresponsible' wildlife management manifests (for example, the keeping of an animal in inhumane conditions) to an extensive wildlife system where natural processes predominate. It therefore covers interrelated domains of animal health and welfare and biodiversity at both a genetic and population level. It is for this reason that the emergence of selective breeding and intensive management of antelope and lions in South Africa has raised concern within the broader conservation and hunting fraternity and particularly the conservation agencies in the country.

Within the above context, this article explores and derives an understanding of the relationship between the public trust, responsible wildlife management and research, using commercial selective breeding and intensive management of components of wildlife as a point of reference.

\section{Commercial wildlife management and genetic integrity}

The pollution of a gene pool of a population through hybridisation, inbreeding or other types of genetic manipulation poses a wide and long-term threat, which may never be corrected, and, as such, if not avoided at the outset, would constitute grossly irresponsible wildlife management from a biodiversity conservation management perspective (Allendorf et al. 2001; Crispo et al. 2011). This concern is exacerbated by the recent acceleration in the commercialisation of wildlife that has resulted in, inter alia, movement of species out of their natural ranges, mixing of subspecies, selective breeding and intensive management for uncommon colour variants or enhanced physiological traits or progressive removal of trophies from a wild population by way of hunting (Mysterud \& Bischof 2010; Trailla, Schindler \& Coulson 2014). While it may be argued that each event in isolation would have an insignificant negative impact on genotypes of the wildlife population or biodiversity as a whole, the same cannot be argued from a cumulative and a broad-scale perspective. This is particularly relevant given that South Africa's wildlife heritage predominantly occurs on private land and private game farms, and this is where most selective breeding and intensive management of wildlife phenotypes are likely to take place (Taylor, Lindsey \& Davies-Mostert 2015).

The disquiet about the cumulative impacts of the commercialisation and associated genetic manipulation of wildlife may be aptly described in the arguments expressed in Hardin's 'Tragedy of the Commons' (Hardin 1968). This being that in the absence of an understanding of, and in part taking responsibility for, the cumulative risk to the country's wildlife emanating out of what may be seen as a 'free ride' or apparent individual right (Stone 2012) to exploit wildlife as personal property, the integrity of wildlife is likely to fail (Ostrom 1999). This argument is particularly relevant where users of wildlife resources adopt a norm-free strategy to maximise short-term gains. Drawing on the economic reasoning of Khan (1966), the 'special status' acquired by most threatened and endangered biodiversity results from a 'series of small decisions' (Odum 1982). Here, a series of individually small, potentially economically rational decisions may lead to a reduction in future opportunities to a point where alternatives (untainted wildlife) are irreversibly destroyed (Kahn 1966).

The solution to preventing an erosion of the integrity of wildlife lies in the collective recognition of a common resource pool of wildlife and its genetics followed by a long-term view of the consequences of both individual and cumulative impacts arising from its commercial use. This may be achieved by the application of responsible management through self-regulation, complexed with regulatory surveillance by the wildlife authorities (Short \& Toffel 2010; Van Gestel 2005). Should such a voluntary mechanism not be forthcoming from the private wildlife industry, the government would be obliged to impose such policy or uniform regulations that are necessary to safeguard the integrity of the country's wildlife, although this is significantly less efficient than self-regulation (Ostrom 1999; Ostrom et al. 2012) and requires a higher degree of regulatory surveillance. Notwithstanding the difference in the effectiveness of these two approaches both options are substantially underpinned by the availability and use of empirical research (Dicks et al. 2014; Krausman \& Cain 2013).

\section{Analysis and discussion South Africa's constitution}

It is contended that responsible wildlife management is founded in the common law public trust doctrine, which has been enshrined in section 24 of the environmental right of the Bill of Rights of South Africa's Constitution, which states that:

Everyone has the right-

- to an environment that is not harmful to their health or well-being; and

- to have the environment protected, for the benefit of present and future generations, through reasonable legislative and other measures that-

- prevent pollution and ecological degradation;

- promote conservation; and

- secure ecologically sustainable development and use of natural resources while promoting justifiable economic and social development. (SA - Republic of South Africa: Constitution of the Republic of South Africa, Act 1996)

In brief, because wildlife is a fundamental component of the environment, all people including future generations, as a 
consequence of this environmental right, have an absolute right, as opposed to a progressive right, to have South Africa's wildlife shielded from significant human-induced danger, injury, change and loss. This perspective on rights was set in place by justice Yacoob in the founding case of the Government of the Republic of South Africa v Grootboom.

It is, therefore, a sound argument that South Africa's environmental right in the Bill of Rights encompasses people's right to have South African wildlife safeguarded from significant human-mediated genetic change. This brings into play both moral and ethical considerations relating to changes in the phenotypes of species through the over-accentuation of uncommon genes or gene associations, leading to what are commonly described as 'colour-variants'. While the aesthetic value of the phenotypic appearance of individual species falls outside the scope of this article, it remains, together with 'ecological degradation', an important consideration from a constitutional and public trust perspective.

From a broad perspective, the achievement of the environmental right effectively prohibits any use of the country's wildlife in a manner that may be counter to its conservation. The breadth of this right gives credence to the understanding that the protection of the environment includes the protection of the genetic integrity of the country's wildlife. Another pillar of protection is seated in the use of wildlife. Here, any use must be 'ecologically sustainable' in perpetuity in order not to foreclose on, at least, current and future generations' opportunities. Economic and social use of wildlife cannot be at the expense of the integrity of this resource. In short, the environmental right dispels the concept that the ecological integrity of the country's wildlife can be compromised to further economic or social development. Such compromise is likely to be considered unconstitutional and unjustifiable, although this supposition remains to be tested in the Constitutional Court.

\section{The National Environmental Management Act and the public trust doctrine}

In its entirety, the environmental right in South Africa's Constitution embraces to the full the concept of the public trust doctrine prescribed in the National Environmental Management Act 107 of 1998 (NEMA). This Act defines the public trust doctrine as one of a number of principles to be applied to all environmental decision-making undertaken by the government. The public trust principle reads as:

The environment is held in public trust for the people, the beneficial use of environmental resources must serve the public interest and the environment must be protected as the people's common heritage. [Section 2(4)(o)]

The trust principle is further refined by section 3 of the National Environmental Management Biodiversity Act 10 of 2004 (NEMBA), under the heading of 'State's trusteeship of biological diversity'. This section reads as:

In fulfilling the rights contained in section 24 of the Constitution, the state through its organs that implement legislation applicable to biodiversity, must (a) manage, conserve and sustain South Africa's biodiversity and its components and genetic resources, and (b) implement this Act to achieve the progressive realisation of those rights.

The government, through all its organs of state, has a proactive duty to act as a trustee of the environment and the biodiversity and the genetic resources therein. Simply worded, wildlife 'should be held in trust by the state, which must manage its consumptive use and protection on behalf of present and future citizens' (Sagarin \& Turnipseed 2012) or 'the State is the trustee of all natural resources which are by nature meant for public use and enjoyment' (Jain et al. 2012). The public trust therefore stresses the application of the 'doctrine of equality', in both the practical and regulatory domains. It is incumbent on the government to ensure that the regulatory process applied to the use of wildlife is non-arbitrary and guided by the country's Constitution and the environmental principles in NEMA, which are to serve the broader public good. In addition, the application of the public trust doctrine stresses transparency in order to confirm fair access to wildlife resources and continued protection of the national and public interest (Jain et al. 2012). The government therefore has a fiduciary obligation to ensure the safety of the country's wildlife and to protect it from damage. As the trustee of the public trust, when read in conjunction with the environmental right, the government may not allow any erosion of the integrity of the country's wildlife through negligence, lack of capacity, popular or partisan demand, by vote or by the monetary or other desires of a select few. As with all trusts, the government as trustee has a primary obligation to the trust's beneficiaries, the public, and in particular to those who are yet to be born (Redmond 2009). Many of the remaining environmental principles in NEMA (see section 2) underpin the application of the public trust doctrine and therein serve to protect the public's wildlife interest. A selection of the environmental principles is briefly discussed below, by way of example see Blackmore (2015) for comprehensive analysis of the environmental principles.

\section{Environmental principles and provisions underpinning the public trust doctrine in National Environmental Management Act 107 of 1998}

The first principle states that any environmental decision taken by government 'must place people and their needs at the forefront of its concern'. The use of the term 'people' embraces the plurality of contemporary society and of future generations. This principle renders it inappropriate for the government to service the needs of an individual, or organisation, or a limited group of people at the expense of the integrity of wildlife or the fundamental rights of broader society (Blackmore 2015; Brundtland Report 1987). It further empowers the government to 'promote the interests of the general public rather than to redistribute [these] public goods from broad public uses to restricted private benefit' (Sax 1970).

The risk-averse principle of NEMA brings to the fore the precautionary principle to environmental decision-making, 
which was first proposed in the 1972 Declaration of the UN Conference on the Human Environment (Stockholm Declaration), and later in the Rio Declaration on the Environment and Development and the Convention on Biological Diversity. The purpose of the risk-averse principle is to anticipate and prevent harm in circumstances where it is perceived that there is a significant degree of uncertainty regarding the potential impact on wildlife (Ramlogan 2011; Trouwborst 2006). With this principle, when applied with the common law on the burden of proof and the polluter-pays principle, the obligation lies with the promoter of the suspected harm (e.g. the wildlife owner or breeder) to demonstrate, beyond a reasonable doubt, that no or negligible harm will arise from any of the actions proposed to be taken (Blumm \& Guthrie 2012). It is, therefore, not the duty of either government or the general public to demonstrate the possibility of significant risk to wildlife (Blackmore 2015). The importance of this principle to furthering responsible wildlife management is to ensure that the integrity of wildlife (the trust entity) is not degraded as a result of a lack of understanding by government of the consequences of the decision taken (Blackmore 2015). Should, however, the potential of realised harm to wildlife arise, the polluter-pays principle states that the avoidance, mitigation or remediation of any harm that may arise must be paid by those responsible for the harm. Section 28 of NEMA further places an obligation on the owner or person in control of a person who has a right to use the land, or a person who is responsible for or who directly or indirectly contributed to the pollution, to take 'reasonable measures to prevent the pollution or degradation from occurring, continuing or recurring'. In circumstances where the harming activity has not been authorised by government or cannot reasonably be avoided, the person referred to earlier must 'minimise and rectify' the pollution or degradation. Reasonable measures contemplated in NEMA include an assessment of the impact, cessation of the activity and elimination of the source of the pollution. Failing to undertake such reasonable steps, the government may issue a directive to achieve the necessary protection of potentially affected wildlife. Should the person fail to comply with the directive, it would be deemed an offence in terms of this Act resulting in a significant fine, jail term or a combination of the two. Furthermore, the government in executing its fiduciary duty as the trustee for wildlife may undertake the necessary preventative or remedial measures and recover the costs from the defaulting person or persons. The provision of these measures is to ensure that the public (the beneficiaries of the wildlife trust) do not have to pay the cost of remediation that is necessary to correct or avoid a potential loss in the integrity of wildlife (section 28 of NEMA).

While the ultimate responsibility of policing the wildlife industry lies with the government, the drafters of NEMA recognised the critical role the public plays in bringing the government's attention to a significant threat to the environment or a potential wildlife crime through whistleblowing. Section 31 of NEMA importantly affords all bona fide whistle-blowers (Figure 1) protection from being civilly or criminally liable; or being dismissed, disciplined, prejudiced or harassed for having disclosed pertinent information to the relevant authorities or popular press.

Further, NEMA reaffirms that the environment, and hence wildlife, is part of the broader public trust, by granting the public the legal standing to approach the courts for relief where there is a breach of the provisions of the Act or its environmental principles and, inter alia, the NEMBA or any other statute that provides for the protection of wildlife (section 32). Furthermore, this section of NEMA also grants the public protection against cost order, should their judicial intervention prove to be unsuccessful. Such measures facilitate the access of the public to a decisive mechanism (judicial intervention) to have set aside any decision or action taken by government, which may threaten the public trust entity (Figure 1).

NEMA, therefore, is a solid foundation for responsible wildlife management not only by way of regulation but also by enabling civil society, as immediate beneficiaries of the wildlife public trust, to monitor and evaluate government's compliance with its fiduciary duties.

\section{Wildlife research and the public trust doctrine}

From a research perspective, although not legally binding, the environmental principles provided in NEMA may also apply to research in that they may be used to guide the researcher to apply an ethical responsibility to understand the broad-spectrum context in which the research and provision of information will be used. Likewise, the onus lies with the researcher to provide the wildlife industry or the state with information that is researched and interpreted in a responsible manner. The foundation for this duty lies not only with the professionalism of the researcher, but also with the realisation that the research may be used in decisions that could impact on the conservation of biodiversity. It is obvious, but worth mentioning, that responsible decision-making,

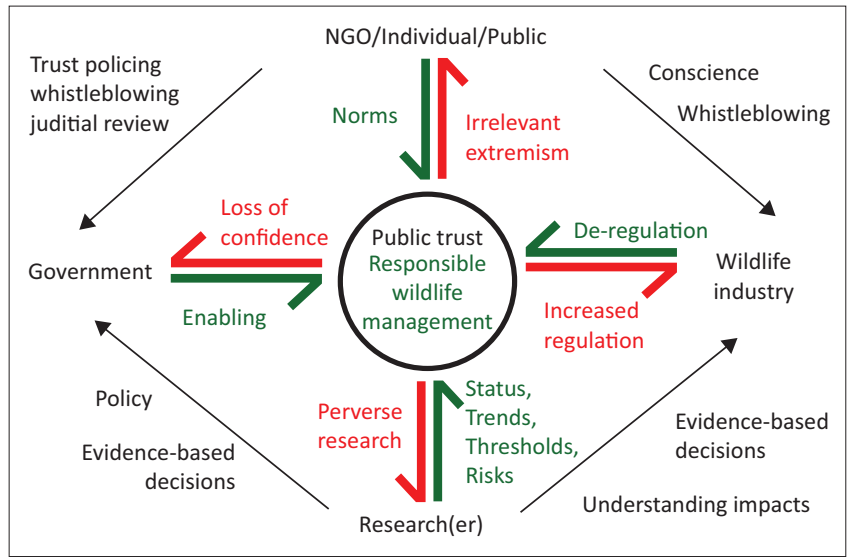

Source: Author's own work

Green arrows denote a positive contribution to the wildlife trust and the red represents an adverse consequence that ultimately undermines the trust and its use.

NGO, non-governmental organisation.

FIGURE 1: Schematic relationship of key role players and their contribution to responsible wildlife management. 
and consequently responsible wildlife management, is fundamentally vulnerable to 'perverse research' in which expedience, falsification, fabrication or misrepresentation of research data prevail (Clavero \& Garcia-Berthou 2005; Fanelli 2009; Van Noorden 2011). Where decisions and policies derived from the research may have far-reaching consequences for wildlife (Figure 1), it is paramount for the researcher to exercise the principle of minimising error through the design of the research, analysis of the data and, importantly, in the interpretation of the findings (Gibbons 2000; Resnik 2015). The relative paucity of wildlife research, however, particularly when compared to other disciplines (e.g. human health), accentuates the vulnerability of the wildlife decision-making sector to the consequences of capricious research, in that such research is unlikely to be effectively overturned or set aside. In these circumstances, this unreliable information is likely to persist and influence decisions for time immemorial (Van Noorden 2011). Thus, significant negative impacts on wildlife resulting from a commercial or other use are not likely to be avoided, mitigated or ameliorated in the short to medium term, exposing the wildlife trust entity to ongoing and cumulative damage that may not be reversible or remediated. This concern is particularly relevant when the quality and quantity of the wildlife resource are eroded towards its sustainable use threshold (Figure 2). There is, therefore, a moral and ethical responsibility and a moral duty of care placed at the door of all researchers, their institutions and funding agencies to ensure that both the research and the interpretation thereof remain robust, accurate and relevant, independent and unbiased (Myhr \& Traavik 2002; Pullin \& Knight 2003).

Furthermore, contemporary thinking on the undertaking of research places an additional dimension of responsibility on the researcher, research institutions and the funders of research to ensure that derived science is 'socially robust' (Nowotny, Scott \& Gibbons 2001). Lubchenco (1998), Nowotny et al. (2001), Löbrand and Öberg (Sarewitz 2004)

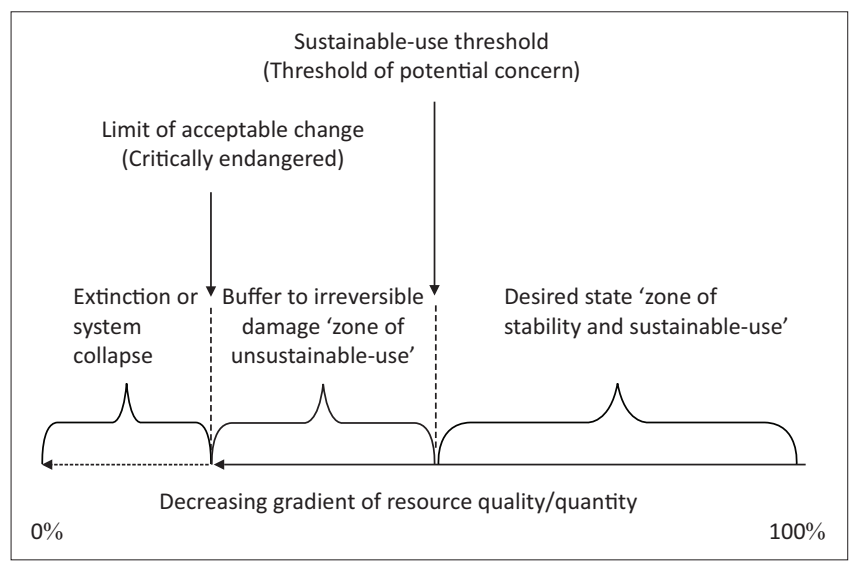

Source: Author's own work

The 'sustainable-use threshold' represents that threshold beyond which there is significant uncertainty whether recovery is possible given the influence of other unrelated system dynamics or disturbances. The term 'limits to acceptable change' is concerned with that point beyond which there is a high likelihood of serious or irreversible damage or harm (viz extinction of a species or habitat).

FIGURE 2: Diagrammatic representation of the sustainable use threshold on a diminishing resource gradient (after Blackmore 2015). and others have argued that this dimension requires that the research undertaken is not only scientifically steadfast, but also 'context sensitive' in that it must take into consideration the needs and expectations of broader society. By stating this aphorism, it is acknowledged that the benefits to be gained by an individual or a select few cannot be at the expense of society whether current or future (Blackmore 2015; Bruskotter, Enzler \& Treves 2011). Such arguments, in the undertaking and application of research, naturally have strong parallels in the application of the public trust doctrine and the duty of care therein. Given that research, perspective and approach of wildlife scientists have a key and positive contribution to policy, this domain will be vulnerable to the pressures of advocates for a particular use of wildlife, or the broader environment, in support of or to further their potentially unsustainable agenda (Pielke 2004).

The application of the public trust doctrine to wildlife research resonates predominantly in two interlinked domains. The first is generating a defendable understanding of the status of the wildlife resource under consideration. This understanding goes beyond describing the species and its distribution, population trends and genetic integrity and must take into account all the threats, perturbations (e.g. drought, climate change) and natural dynamics of the wildlife resource. However, it must also bring to the fore the information that ensures that the anticipated use of wildlife (from at least a meta-population perspective) remains sustainable and stable over time (Figure 2). The second domain is founded on providing sound information: (1) presented in an understandable manner so that the government authority, wildlife manager or self-regulating entity can exercise his or her discretion in a manner that promotes both the public's legal and practical interests together with reducing the vulnerability of wildlife to its use, and (2) which conveys not only the status of the wildlife resource but also the scope of the discretion that can be exercised by the decision-maker from a sustainable use perspective. The scope of this discretion may be determined by the position of the wildlife entity in the 'recourse quality or quantity gradient' (Figure 2), complexed with the confidence with which that position was determined. The closer to the sustainable use threshold or a lower degree of confidence in locating this position on the resource quality or quantity gradient, the higher the risk of significant damage to the wildlife entity under consideration (Figure 2). Under these circumstances, the cautious and risk-averse principle should be strictly applied in decisions regarding the proposed use of the wildlife entity. The narrative generated by the researcher in this regard thus needs to clearly demonstrate these considerations as well as any other uncertainties that may apply. Alternatively, in the absence of a defined or reliable sustainable use threshold, the wildlife user would need to demonstrate that the component of wildlife is being used in a manner that promotes the interests of society or which does not 'impair substantially, the public interest in the remaining [component of the resource]' (Illinois Central Rail Road Co. v. Illinois 1982). It is therefore incumbent on the self-regulatory entity, but ultimately on the government as 
the fiduciary trustee, to ensure, at a minimum, that the cumulative use of wildlife is maintained above the sustainable use threshold (Figure 2). Naturally, this threshold should be set well above the natural dynamics of the wildlife resource so that any perturbations and threats (e.g. climate change, disease) that may or are likely to occur do not have a significantly adverse impact on the integrity of the wildlife resource. Here, defining a point of reference and thereafter demonstrating that the quality and quantity of South Africa's wildlife are being maintained above the 'sustainable-use threshold' should be a crucial focus for researchers and research institutions, as well as the wildlife industry.

\section{Research and the sustainable use threshold}

The complexity of determining the sustainable use threshold (Cairns 2004) requires an ongoing and systematic undertaking and synthesis of wildlife research, and, importantly, the condensing of this information to inform policy within government (Dicks et al. 2013; Leslie et al. 2014). To achieve this, research institutions and funders of research would need to extend their pursuits from a purely theoretical base to include applied science, with the express intention of influencing policy that guides self-regulatory management, and, importantly, government decision-making (Rose 2014). This change in focus would naturally require conservation scientists and research institutions to have not only a fundamental understanding of the provisions in law that require the policy to be in place, together with the process followed by government in applying the policy in decisions affecting wildlife, but also an understanding of the importance and application of the public trust doctrine. Without this understanding, it is unlikely that the outcomes of the research would have the desired impact on the decisions ultimately taken by government to safeguard the wildlife trust entity. This challenge is described as 'constructing a compelling conservation narrative' (Rose 2014), drawing on arguments that are focused, inter alia, on contextualising research within the public trust philosophy and highlighting the solutions and consequences of nonaction (Van Bommel \& Zouwen 2012). The description of the 'non-action option' should further highlight the immediate and potentially cumulative impacts on the wildlife trust entity. The derivation of this compelling argument requires an understanding of the decision-making processes and thus may require frequent, and with a high degree of clarity and simplicity, effective engagement with either government or the self-regulating wildlife industry (Basken 2009).

As a means to ensure appropriate consideration of the potential impact on the wildlife trust entity, researchers or decision-makers may apply a series of principle questions that guide an assessment on whether the biodiversity trust entity would be at risk (Blackmore 2015). These questions, listed below, are in many respects overlapping and probe different aspects of potential long-lasting or irreversible impacts on the trust entity. In so doing, they form the beginnings of the 'context-sensitive' framework discussed earlier to guide the focus of the research necessary to inform and guide policy and decisions made by government. It also gives the government official, researcher and the wildlife industry a framework to determine whether the sustainable use threshold (Figure 2) has been or is at risk of being transgressed, or whether the observed or proposed use of the wildlife is sustainable in its true form. The answers to the following questions (extracted from Blackmore 2015), therefore, provide insights as to whether the public wildlife trust entity has been appropriately safeguarded:

- Is the biodiversity involved rare, unique, endangered, or does it have significant historical significance?

- Is that component of biodiversity used or impacted upon easily replaced?

- Will the proposed action or decision have any significant consequential effect on other actions or initiatives that provide for the conservation of biodiversity?

- Are the negative consequences of an action or decision realistically or reasonably reversible?

- Can damages or costs for mitigation and amelioration of negative consequences be reasonably recovered from those responsible for the environmental damage?

- Have the cumulative impacts of human activities on the elements of biodiversity under consideration not exceeded any sustainable use threshold?

- Is there sufficient confidence (i.e. defendable information) that the trust object will not be damaged?

- Will the impacts of the activity be reasonably mitigated or remediated within a meaningful timeframe, or in the foreseeable future, or within a period that ensures strict compliance with the conditions of the decision?

- Will the realisation of potential economic and social benefits that require the safeguarding of biodiversity be compromised?

In answering these questions, the government official is enabled to:

(1) consider the potential adverse impacts of any proposed activity over which it has administrative authority; (2) allow or grant permission to undertake such activities that do not substantially impair the state's wildlife resources; (3) continually monitor the impacts of an approved activity on the wildlife to ensure preservation of the corpus of the trust; and (4) bring suit under the parens patriae doctrine to enjoin harmful activities or to recover for damages to wildlife. (Musiker 1995)

\section{Public rights in terms of protecting wildlife}

As the beneficiaries of the trust, drawing on the environmental right read with the right to access to information and just administrative action (sections 32 and 33, respectively) in the Bill of Rights, the public have a constitutional right to be informed of any activity that may have a negative impact on the wildlife trust entity. It is for this reason that NEMA requires the general public to be consulted (public participation) when a damaging activity is being considered by an applicant (section 47B). This enables an aggrieved person or group of persons to appeal (section 43) the decision when such decision erodes the public trust entity or the public's fundamental right to have the environment protected 
from harm (Figure 1). Furthermore, NEMA provides an opportunity for any person or group of persons to seek the intervention of the courts to enforce compliance with a statutory provision (including the environmental principles) relating to the protection or use of the environment. Relief from the courts may, inter alia, be achieved in one's or the group's own interest, in the interest of a class or group of persons unable to institute legal action (i.e. future generations), in the public interest or in the interest of protecting the environment (section 32) (Figure 1). The NEMA further entrenches the paramount importance of safeguarding the public trust, by: (1) providing the courts leave to waver a cost order should the applicant have acted, inter alia, 'reasonably out of a concern for the public interest or in the interest of protecting the environment', and (2) allowing any person of the public to initiate and conduct a private prosecution where there are reasonable grounds to believe an offence has been committed (section 33).

The constitutional imperative to protect the public trust and the rights of the public to ensure that the trust entity is safeguarded is also reflected in the Promotion of Access to Information Act 2 of 2000 (PAIA) and the Promotion of Administrative Justice Act 3 of 2000 (PAJA). PAIA provides a statutory mechanism for the public to gain access to information that may be important for the protection of any rights. PAJA provides a legal mechanism for the public to ensure that an administrative action (i.e. a decision or importantly failure to make a decision) is lawful, reasonable and procedurally fair. PAJA also provides a mechanism to take a decision (or failure to make a decision) by government on judicial review (Figure 1). Such a review may result in, inter alia, the decision being set aside, a condition to the decision being changed or others added, or in a mandamus ordering an official to perform a public or statutory duty where the official has failed to do so. Finally, NEMA provides specific protection to whistle-blowers (section 31), who, in good faith, believe that the disclosure of information or a circumstance was reasonably warranted to avoid or address an imminent threat to the trust entity and the wildlife therein.

The public are thus granted a substantial amount of legal power and protection to 'police' the use and status of the country's wildlife. Imbedded in this is the key role the public ought to play in directing the conscience of the wildlife industry and government (Figure 1). As the beneficiary of the public trust, it is incumbent on the public to exercise this vehicle in the public interest to ensure that responsible management of wildlife prevails. This duty extends to playing an active role in monitoring the decisions taken to authorise various uses of wildlife, the promulgating of new legislation that relates to relaxing constraints on the use and management of wildlife, and the practices of the wildlife industry. The NEMA and PAJA require that potential threats to wildlife or its environment be resolved through the various appeal (including whistle-blowing) mechanisms provided in this legislation. These mechanisms need to be exhausted, unless the threat constitutes an emergency, before seeking relief from the courts. While it may be argued that 'environmental extremism or purism' has played a role in strengthening the protection of individuals of a threatened species, or occasionally threatened habitat and ecosystems at or below the limit of acceptable change (Figure 2), this approach has had little success, at least in recent years, in terms of revising environmental policy (Posluszna 2015). This observation also applies at the decision level, where often the approach taken by government is to balance consumptive needs and the need to protect the environment. Here, environmental extremism is often dismissed by the decision-maker as unreasonable or irrelevant (Figure 1). In contrast, a rational and principled approach to engaging with the government or the wildlife industry on matters regarding the public trust places the public in a robust position to guide both these sectors at the decision-making level as well as influencing, if not directing, wildlife policy (Figure 1). Furthermore, the public set the moral and ethical norms that drive responsible wildlife management, either directly by way of opinion, or via the courts. These norms affirm the intrinsic value of wildlife in a natural form that underpins its economic value for non-consumptive tourism, hunting and trade (Child 1970). The development and imposition of these norms are the core of the trust standard to be applied by both government and the wildlife industry. In essence, the public trust doctrine provides a 'common-law check-and-balance' that monitors and holds the government accountable for its administrative actions and the industry's use of wildlife (Ryan 2004).

As the trustee for wildlife, government is ultimately accountable for the integrity of the wildlife trust entity. A decline in the public's confidence in government to manage and safeguard the public trust leads to a lower rate of compliance with policy and regulatory frameworks (Figure 1) (Organisation for Economic Co-operation and Development [OECD] 2013). While the public have an independent role to voice their confidence (or distrust) in government's policies and its compliance with these, it is not uncommon for the public to place their trust in the very organ of state democratically appointed, and hence ultimately mandated, to conserve and protect wildlife. This is particularly so if there is low confidence in the wildlife industry's ability to undertake responsible wildlife management through selfadministration. This, in turn, results in an increased demand for regulation and policing (Aghion et al. 2010).

The same is also argued for a declining wildlife resource, particularly when the status of this resource has traversed the sustainable use threshold and is considered endangered or facing extinction (Figure 2). In such circumstances, the government is obliged to exercise its fiduciary duty, emanating from the environmental right within the Constitution, together with the public trust principle within NEMA to impose greater regulation and in extreme cases impose a prohibition on the use of wildlife. The implementation of the 2007 Threatened or Protected Species Regulations to the NEMBA serves to illustrate such fiducial action. The converse of this argument also holds, in that 
should the industry effectively maintain a high standard of responsible wildlife management, confidence is generated within both the public and government. This, in turn, would lead to greater enabling environmental policy and ultimately regulation being replaced with self-regulation (Figure 1). The history of 'deregulation' in the wildlife industry and in the broader environmental sector has been a troubled one in that lobbyists for deregulation have often had a private economic agenda that is exploitative and to the detriment of the wildlife trust. In such circumstance, objective and independent evaluation of the standards of the self-regulation of the wildlife industry is required to be set in place in order to avoid undue influence by such conflict of interest.

\section{Conclusion}

Although deeply rooted in South Africa's Constitution and environment and biodiversity conservation legislation, the public trust doctrine is largely unknown and poorly understood in the broader wildlife management and research arenas. Despite this, the doctrine remains a powerful tool for both the government and the public to limit the impacts of parochial interests that promote exploitation over wildlife conservation. In addition, the doctrine ultimately provides the impetus, through individuals or groups of individuals acting in the public interest, for evoking judicial action for the courts to hold the government accountable to its trust obligations, in order to safeguard the integrity of the country's wildlife. The impacts of the commercialisation, and in particular genetic manipulation, of wildlife are riddled with uncertainty. Consequently, outside of strict regulation it presents a high risk to the integrity of this natural resource. Against this background, it is further concluded that it is critical that the public trust be understood and brought into the discourses of and narratives leading to decisions taken by government or the wildlife industry, and should also form the foundation of wildlife research undertaken to inform such decisions.

\section{Acknowledgements}

The author would like to thank Professor Arie Trouwborst (Tilburg University) and Ms Lizanne Nel (South African Hunters and Game Conservation Association) for their valuable discussions and well-placed comments. The legal instruments cited and discussed in this article are current, as of 14 April 2017. This article is one of a series of articles forming a PhD which is focused on exploring the significance and scope of the public trust doctrine in the conservation of biodiversity, and the management of protected areas in South Africa. The ideas, arguments and opinions expressed in this article are the author's own and do not necessarily represent those of Ezemvelo KZN Wildlife or the University of KwaZulu-Natal.

\section{Competing interests}

The author declares that he has no financial or personal relationships that may have inappropriately influenced him in writing this article.

\section{References}

Aghion, P., Algan, Y., Cahuc, P. \& Shleifer, A., 2010, 'Regulation and distrust', The Quarterly Journal of Economics 125(3), 1015-1049. https://doi.org/10.1162/ qjec.2010.125.3.1015

Allendorf, F.W., Leary, R.F., Spruell, P. \& Wenburg, J.K., 2001, 'The problems with hybrids: Setting conservation guidelines', Trends in Ecology and Evolution 16(11), 613-622. https://doi.org/10.1016/S0169-5347(01)02290-X

Basken, P., 2009, 'Often distant from policy making, scientists try to find a public voice', Chronicle of Higher Education 27, viewed 3 November 2015, from http:// chronicle.com/article/Often-Distant-From-Policy-M/44410

Blackmore, A., 2015, 'The relationship between the NEMA and the Public Trust Doctrine: The importance of the NEMA principles in safeguarding South Africa's biodiversity', South African Journal of Environmental Law and Policy 20(2) 89-118.

Blumm, M. \& Guthrie, R., 2012, 'Internationalizing the public trust doctrine: Natural law and constitutional and statutory approaches to fulfilling the Saxion Vision', UC Davis School of Law - Law Review 45(3), 741-808.

Brundtland Report, 1987, Our Common Future, report of the World Commission on Environment and Development, published as Annex to General Assembly document A/42/427, Development and International Co-operation: Environment. UN Documents: Gathering a Body of Global Agreements, United Nations.

Bruskotter, J.T., Enzler, S.A. \& Treves, A., 2011, 'Rescuing wolves from politics: Wildlife as a public trust resource', Science 333, 1828-1829. https://doi.org/10.1126/ science. 1207803

Cairns, J., 2004, 'Ecological tipping points: A major challenge for experimental sciences', Asian Journal of Experimental Sciences 18(1,2), 1-16.

Child, G., 1970, 'Wildlife utilisation and management in Botswana', Biological Conservation 3(1), 18-22. https://doi.org/10.1016/0006-3207(70)90053-4

Clavero, M. \& Garcia-Berthou, E., 2005, 'Invasive species are a leading cause of animal extinctions', Trends in Ecology and Evolution 20(3), 110. https://doi.org/10.1016/j. tree.2005.01.003

Cousins, J.A., Sadler, J.P. \& Evans, J., 2010, 'The challenge of regulating private wildlife ranches for conservation in South Africa', Ecology and Society 15(2), 28. https:// doi.org/10.5751/ES-03349-150228

Crispo, E., Moore, J.-S., Lee-Yaw, J.A., Gray, S.M. \& Haller, B.C., 2011, 'Broken barriers: Human-induced changes to gene flow and introgression in animals', BioEssays 33(7), 508-518. https://doi.org/10.1002/bies.201000154

Dicks, L.V., Hodge, I., Randall, N.P., Scharlemann, J.P.W., Siriwardena, G.M., Smith, H. et al., 2014 'A transparent process for "Evidence-Informed" policy making', Conservation Letters 7(2), 119-125. https://doi.org/10.1111/conl.12046

Dobson, A., Lodge, D., Alder, J., Cumming, G.S., Keymer, J., McGlade, J. et al., 2006 'Habitat loss, trophic collapse, and the decline of ecosystem services', Ecology 87(8), 1915-1924. https://doi.org/10.1890/0012-9658(2006)87[1915:HLTCAT]2.0.CO;2

Fanelli, D., 2009, 'How many scientists fabricate and falsify research? A systematic review and meta-analysis of survey data', PLOS One 4, e5738. https://doi org/10.1371/journal.pone.0005738

Gibbons, M., 2000, 'Science's new social contract with society', Nature 402(6761 Suppl), C81-C84.

Government of the Republic of South Africa \& Others v Grootboom \& Others 2000 (11) BCLR 1169 (CC) 19 (S. Afr.).

Hardin, G., 1968, 'The tragedy of the commons', Science 162(3859), 1243-1248. https://doi.org/10.1126/science.162.3859.1243

Hoffmann, L. \& Jungius, H., 1972, 'Conservation in tropical Africa: With special emphasis on the activity of the International Union for the Conservation of Nature and Natural Resources (IUCN) and the World Wildlife Fund', Acta Tropica 29(4), 482-506.

Illinois Central Rail Road Co. v. Illinois, 1982, 146 US 387: 36L Ed 1018.

Jain, D.K., Kapadia, S.H., Misra, D., Gogoi, R. \& Singh, K.J.J., 2012, 'Advisory jurisdiction Legal opinion, Supreme Court of India. No. 1 [Under Article 143(1) of the Constitution
of India - Reportable]', viewed 23 March 2016, from http://www.lawnotes.in/Under_ of India - Reportable]', viewed 23 March 2016,
Article_143(1)_of_the_Constitution_of_India

Jewitt, D., Goodman, P.S., Erasmus, B.F.N., O'Connor, T.G. \& Witkowski, E.T.F., 2015 , 'Systematic land-cover change in KwaZulu-Natal, South Africa: Implications for biodiversity', South African Journal of Science 111(9/10), Art. \#2015-0019, 1-9, biodiversity', South African Journal of Science 111(9/10), Art. \#2015-0019, 1-9, 1 ,
viewed 10 August 2016, from https://doi.org/10.17159/sajs.2015/20150019

Kahn, A.E., 1966, 'The tyranny of small decisions: Market failures, imperfections, and the limits of economics', Kylos 19(1), 23-47. https://doi.org/10.1111/j.14676435.1966.tb02491.x

Krausman, P.R. \& Cain, J.W. (eds.), 2013, Wildlife management and conservation: Contemporary principles and practice, John Hopkins University Press, Baltimore, MD.

Leslie, H.M., Goldman, E., Mcleod, K.L., Sievanen, L., Balasubramanian, H., CudneyBueno, R. et al., 2013, 'How good science and stories can go hand-in-hand', Conservation Biology 27(5), 1126-1129. https://doi.org/10.1111/cobi.12080

Lubchenco, J., 1998, 'Entering the century of the environment: A new social contract for science', Science 279, 491-497, viewed 7 September 2017, from http:// science.sciencemag.org/content/279/5350/491.full

Luxmoore, R., 1985, 'Game farming in South Africa as a force for conservation', Oryx 19(4), 225-231. https://doi.org/10.1017/S0030605300025667

Musiker, D.G., France, T. \& Hallenbeck, L.A., 1995, The public trust and Parens Patriae Doctrines: Protecting wildlife in uncertain political times, Public Land and Resources Law Review 16, 87-116. 
Myhr, A.I. \& Traavik, T., 2002, 'The precautionary principle: Scientific uncertainty and omitted research in the context of GMO use and release', Journal of Agricultural and Environmental Ethics 15, 73-86. https://doi.org/10.1023/A:1013814108502

Mysterud, A. \& Bischof, R., 2010, 'Can compensatory culling offset undesirable evolutionary consequences of trophy hunting?', Journal of Animal Ecology 79(1) 148-160. https://doi.org/10.1111/j.1365-2656.2009.01621.x

Nowotny, H., Scott, P.B. \& Gibbons, M.T., 2001, Re-thinking science: Knowledge and the public in an age of uncertainty, Polity Press, Cambridge.

Odum, W.E., 1982, 'Environmental degradation and the tyranny of small decisions', BioScience 32(9), 728-729. https://doi.org/10.2307/1308718

Organisation for Economic Co-operation and Development (OECD), 2013, 'Trust in government, policy effectiveness and the governance agenda', in Government $a$ a glance, OECD Publishing, viewed 28 October 2015, from https://doi.org/ 10.1787/gov_glance-2013-6-en

Ostrom, E., 1999, 'Coping with tragedies of the commons', Annual Review of Political Science 2, 1-565. https://doi.org/10.1146/annurev.polisci.2.1.493

Ostrom, E., Chang, C., Pennington, M. \& Tarko, V., 2012, 'The future of the Commons Beyond market failure and government regulation', Institute of Economic Affairs Monographs, Indiana University, Bloomington School of Public and Environmental Affairs Research Paper No. 2012-12-02, viewed 30 May 2016, from https://doi org/10.2139/ssrn.2267381

Pielke, R.A., 2004, 'When scientists politicise science: Making sense of the controversy over the skeptical environmentalist', Environmental Science \& Policy 7, 405-417. https://doi.org/10.1016/j.envsci.2004.06.004

Posluszna, E., 2015, Environmental and animal rights extremism, terrorism, and national security, Elsevier/Butterworth-Heinemann, Boston, MA.

Pullin, A.S. \& Knight, T.M., 2003, 'Support for decision making in conservation practice: An evidence-based approach', Journal for Nature Conservation 11, 83-90. https:// doi.org/10.1078/1617-1381-00040

Ramlogan, R., 2011, Sustainable development: Towards a judicial interpretation, Martinus Nijhoff Publishers, Boston, MA.

Redmond, P., 2009, 'The public trust in wildlife: Two steps forward, two steps back', Natural Resources Journal 49, 249-331.

Resnik, D.B., 2015, 'What is ethics in research and why is it important?', viewed 7 Apri 2016, from www.niehs.nih.gov/research/resources/bioethics/whatis

Rose, D.C., 2014, 'The case for policy-relevant conservation science', Conservation Biology 29(3), 748-754. https://doi.org/10.1111/cobi.12444

Ryan, P.S., 2004, 'Application of the public-trust doctrine and principles of natural resource management to electromagnetic spectrum', Michigan Telecommunications and Technology Law Review 10(825), 285-372.

SA - National Environmental Management Biodiversity Act 10 of 2004.

SA - Promotion of Access to Information Act 2 of 2000

SA - Promotion of Administrative Justice Act 3 of 2000
SA - Republic of South Africa: Constitution of the Republic of South Africa 1996.

SA-Threatened or Protected Species Regulations (TOPS) to the National Environmental Management Biodiversity Act 10 of 2004, published as Government Notice R152 in Government Gazette G 29657 of 23 February 2007.

SADC, 1992, Treaty of the South African Development Community, Southern African Development Community, Kinshasa, Congo.

Sagarin, R.D. \& Turnipseed, M., 2012, 'The public trust doctrine: Where ecology meets natural resources management', Annual Review of Environment and Resources 37, 1-496. https://doi.org/10.1146/annurev-environ-031411-165249

Sarewitz, D., 2004, 'How science makes environmental controversies worse by $E$ Löbrand, and G Öberg', Environmental Science and Policy 7, 385-403. https://doi. org/10.1016/j.envsci.2004.06.001

Sax, J.L., 1970, Defending the environment: A strategy for citizen action, Knopf, New York.

Short, J. \& Toffel, M.W., 2010, 'Making self-regulation more than merely symbolic: The critical role of the legal environment', Administrative Science Quarterly 55, 361396. https://doi.org/10.2189/asqu.2010.55.3.361

Stone, C.D., 2012, Should trees have standing?: Law, morality and the environment, 3 rd edn., Oxford University Press, Oxford.

Taylor, W.A., Lindsey, P.A. \& Davies-Mostert, H., 2015, An assessment of the economic, social and conservation value of the wildlife ranching industry and its potential to support the green economy in South Africa, The Endangered Wildlife Trust, Johannesburg.

Trailla, L.W., Schindler, S. \& Coulson, T., 2014, 'Demography, not inheritance, drives phenotypic change in hunted bighorn sheep', Proceedings of the Nationa Academy of Sciences 111(36), 13223-13228. https://doi.org/10.1073/pnas. 1407508111

Trimble, M.J. \& Van Aarde, R.J., 2014, 'Supporting conservation with biodiversity research in sub-Saharan Africa's human-modified landscapes', Biodiversity and Conservation 23(9), 2345-2369. https://doi.org/10.1007/s10531-014-0716-4

Trouwborst, A., 2006, Precautionary rights and duties of states. Nova et vetera iuris gentium, Martinus Nijhoff Publishers, Leiden.

Van Bommel, S. \& Van der Zouwen, M., 2012, 'Creating scientific narratives: Experiences in constructing and interweaving empirical and theoretical plots', in B. Arts, J. Behagel, S. Van Bommel \& J. De Konin (eds.), Forest and nature governance: A practice based approach (pp. 217-239), Springer Science, Dovernant.

Van Bommel, S. \& Van der Zouwen, M., 2012, 'Creating scientific narratives: experiences in constructing and interweaving empirical and theoretical plots', in Forest and Nature Governance (pp. 217-239), Springer, Netherlands.

Van Gestel, R., 2005, 'Self-regulation and environmental law', Electronic Journal of Comparative Law 9, viewed 22 May 2016, from http://www.ejcl.org

Van Noorden, R., 2011, 'The trouble with retractions: A surge in withdrawn papers is highlighting weaknesses in the system for handling them', Nature 26 , viewed 30 May 2016, from http://www.nature.com/news/2011/111005/full/478026a.html 